\title{
GENERATIVE CREATING OF SACRAL SPACE: MYTHOLOGY, COSMOLOGY AND PLACES FOR CULT RITUALS
}

\author{
Silvija Ozola \\ Riga Technical University, Latvia
}

\begin{abstract}
Signs are an integral part of the existence of humanity. The Latvians have one of the most complicated symbolic sign system in the world-the Lielvārde belt which includes symbols of strong energy and encodes ancient information that characterizes the special relation to nature and the Universe. God is the basis of moral values and the origin of all events. The understanding of Latvian deities is based on creative thought, and each sign of the deity image is a structural whole with a certain informative value. The Balts' tribes for cult rituals chose energetically powerful places. Generative creating of sacral space and religious ritual is connected by concepts the Place, the Way and the Symbol. Research object: Latvian wisdom and spiritual traditions, sacral space for the worship of God. Research goal: analysis of the influence of the Latvian wisdom on traditions of the establishment of early places of worship. Research problem: common and different features of the sacral space of the Latvians and other nations have been little studied. Research novelty: detailed studies of generative creating of early places of worship based on Latvian mythology and cult ritual traditions of other nations. Research methods: analysis of archive documents and cartographic materials, study of published literature and inspection of sacral places in nature.
\end{abstract}

Keywords: evolution, generative creating, Latvian mythology, Latvian wisdom, red white Lielvārde belt, sacral space, system of geometrical signs.

\section{Introduction}

Every nation, in its historical times, similarly as its own language, also has its own honour and self-esteem or ethics based on the creative exploration of the Universe or the World and God's presence, nature and a person. God is the basis of moral values, the origin of all events everywhere and the causality of the whole beginning and the spiritual origin. God decides on the fate of the person, creates and expands the Universe, which principle of existence is the order of things and eternal changeability through constant creating and recreating. God, who comprehendes cosmic intelligence, rules the Universe with the help of nature laws. Nature is alive, figurative and sacral for the Latvians and also the Balts. The presence and creativity of God is the soul - the common essence of all matters and the human being's eternal, timeless part associated with the centre of every process. God without the time and spatial dimensions always present as the 
highest advice of advice and its creative thought cannot be discovered completely. God as the source and causality of everything, the World's soul and the guard of virtues and legal order is manifested in the World's four basic elements - earth, fire, water and air - and also four cardinal directions, east, west, north and south. Latvian wisdom is based on God's realization and the Universe creative cognition. Relationships with God are friendly. They are not relationships of a master and servant or master and slave. In Latvian folk songs, God, like an old, just dressed man similar to a farmer everywhere present among the people and encourages good things - works and thoughts. God brings blessings to the earth, to the people, sets the course of celestial luminaries, thinks, knows, allows, gives, helps, guards, protects, takes care, raises, develops the World, which is full of life forces. God is an infinite, all-bright and good representative, benefactor, giver of counsels, the former, the current and the almighty one. Everything is one. God is both spirit and matter. On an initial level, it is thought that soulful energy is the light. It gradually transforms into formations of material nature. God is united in the diversity of all its expressions and wholeness of His manifestations (Celms, 2016).

In God, all opposites are united - light and darkness, father and mother and good and evil. God just is, but one for everyone. Where does this infinite God lie? God is everywhere: in the middle of the yard, on the edge of the road, in bushes of the roadside, behind the hill, even under the grey stone. Latvian folk songs, signs and symbols tell about God's outcry in the Universe, nature and a person for a unified vision, where God is a human helper, travelling companion, adviser. Every long way starts with the first step. The World connected with real life is creative, active, joyful. A person who is given the opportunity to gain happiness by serving good and morally to grow himself makes up his life (Celms, 2016).

The Latvian consciousness of God and the worldview formed on the thousands of years of Proto-Indo-European or Baltic external culture is encoded in the red white Lielvārde belt up to $270 \mathrm{~cm}$ long (Fig. 1) used as womenfolk costume's element of the Daugava River surroundings. The Latvian pattern created by 22 signs into different combinations (Fig. 2) has an overall organizing impact and principal functions - to arrange and informs about spiritual, physical and astral levels and special relations to nature and the Universe. Geometric signs arranged in ornaments (Latin: ornamentum) to decorate and to be decorated, and to pass the particular family's, people's or nation's wisdom and living skill to next generations are an integral part of the existence of mankind and a way of communication. One of the richest and most complicated systems of geometrical signs in its most ancient beginning similar to language is a natural phenomenon. It embodies possibilities of development in the future, the feeling code of the Latvians' life and tasks for art, environment, spirit. The united system of signs is described by structural oneness and the development from simplest to the most complicated. All signs develop and arrange according to this principle. This 
system has to be looked like a set of cyclic motions, where signs are eternal mediators that provide communication or exchange information between the person and the natural environment and symbolize stages of different movements. Signs are able to provide much information as it is impossible to express in words. One sign changes into another moving into time and space. It is not only translated through another but also develops, grows and turns from one another. The same sign can appear in several places but with a different symbolical meaning. It complies with the universal essence of a sign's geometrical construction and symbol's polysemy: a sign is revealed through another sign but the image through another image. The strict construction of the system's internal links allows some complimentary variations and manifestations. Geometrical signs covers all levels of manifestation. Each view highlights one or a few qualities but does not exhaust the whole nature. Symbolic signs as the most laconic and ancient form of information do not have any nationalities and present spiritual reality, visible and invisible layers of our existence and connect polarities in one whole. Meanings of symbols have not disappeared in nonexistence. Everyone must rediscover itself, like the World, which is so wide, how wide is the human consciousness of its observer. Latvian cultural symbols by their powerful energy and protective magic encompass people's special connection with nature and the Universe. The base of Latvian god comprehension is creative thought. Latvian mental tradition has enriched the ancient heritage of European and world's culture (Ozola, 2017).
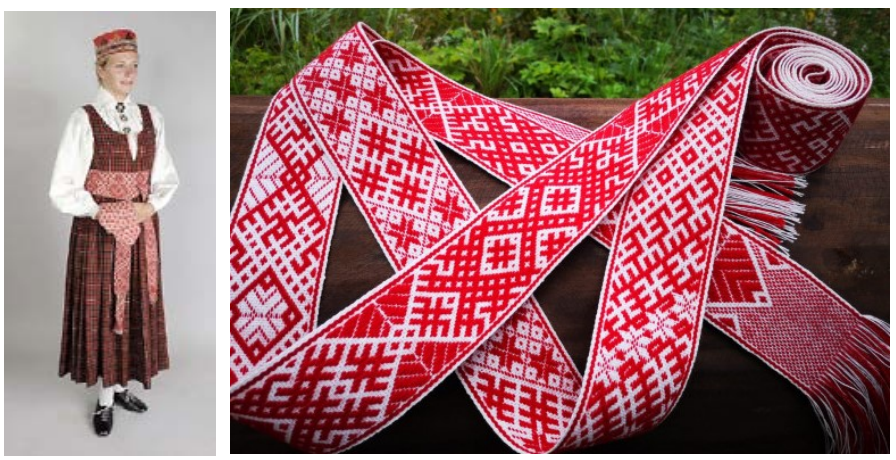

Figure 1 Photographer Normunds Grasis. Latvian womenfolk costume by the Lielvärde belt (online 07.05.2019, source: http://i7.tiesraides.lv/340x340s/galleries/epadomi_ lv/4db002c61ab7a/2011-05-19_dsc8330.jpg)

Figure 2 Geometric signs in the pattern of the red white Lielvärde belt (online 24.02.2021, source: https://www.egadatirgus.lv/pictures/scs-5f34da916e363.jpg)

Everything in sign symbols starts with the smallest element of the pattern's structural construction. The first flash of consciousness in darkness is the smallest dot which as the beginning and the end of something symbolizes an individual object, thought, idea, impulse and also the light of the soul given to a human being 
at birth. The source of light's energy manifests God's presence on every step and helps us to find the best solution. In Latvian folklore, the central and main light of the sky is the Sun. It is a symbol of eternal movement and life. The principal form of the Sun's Sign is rhombus or a closed circle with a marked centre. The circle with a dot in the centre symbolizes the Sun and the Universe, the beginning of the World from a bud and a nucleus and also the unity of the male and the female. In the Sun's Sign, concentric circles around the centres of the nucleus manifest the idea of radiation and pulsation and mark a new direction of motion from the centre to sides and back to the centre, which is the beginning and the end of all events. In the language of symbolic signs, the World is marked by the circle which makes up the Sun's run: the upper semicircle symbolizes the day and this World, but the lower semicircle - the night and the Underworld situated in another dimension beyond borders of the visible world. In the centre of the circle, but in another dimension, is the Afterworld or the World of post-death, where God's supreme advice or the highest thought that is visible in the middle of any expression lives. The Way to the Afterworld passes through the Underworld. The World's motion life and death correlate as etiological and natural events of a big course. Every individual life finishes eventually in order to provide a place for another one: such is the natural law accepted by the Latvians in a deep understanding.

Extending the dot, a line is formed. The line can be positioned vertically or horizontally; it can also be slanted. Dots and lines can be crossed or grouped, supplemented with other dots and lines. This is how sign symbols are created. A little cross marks the centre of all activities where the World starts from. God's Sign is a cross with four equal-length branches, which can stretch out infinitely similarly to the spiritual world that is infinite beyond all borders of the material world. The little cross with the dot or eye is a star. God's or Golden Cross has two different states of varied meaning: the straight or rigid cross is stopped energy, peace, non-creating state, darkness, death, immobility and rigidity, but the slanted or moving, also rotating cross, called the transverse cross, characterizes liberated energy, anxiety, life force, light, restlessness, creative position and the World's cyclic movement created by God - rotation, where life alternates death as logical and natural events. Straight God's Cross (Fig. 3) is the sign of the World's order which points to immobility and passivity and symbolizes the orientation of four kinds, centre, infinity, unity of material and ideal, as well as the timeless space the World and also the Underworld. Slanted God's Cross (Fig. 3) is the sign of the World's order in the position that points to motion and symbolizes activity, dynamics, but at the same time preserving the World's orientation of four kinds, the symbolism of the material and ideal unity included into one sign. Slanted God's Cross as a solar sign - the Sun Wheel or Cross of Rays (Sun Cross, Solar Cross, or Wheel Cross) symbolizes the centre, infinity, the World's rotation 
(Fig. 3), division of time and space into eight symmetrical parts, also combines life and death aspects set by God's order. Both crosses in one sign show the coexistence of this World and the Underworld and the cyclic change of light and dark and life and death. The Star's Sign on the border between this World and the Underworld preserves an open outline. Rays of the star coming out from the centre can continue infinitely. The Sun Wheel and the Star's Sign included in one sign symbolize the simultaneous existence of this World and the Underworld. During the day, the Sun moving in the sky is in the slanted cross position. In the evening it dies and is situated in the straight cross position. Duality is symbolized by the Sun Wheel included in the Sun's Sign which divides the circle into days and nights, good times and hard times, as well as a prediction about the Underworld in plans of another existence and temporariness of this World, emphasizing its cycle. Signs show the Sun's course strictly geometrical and symmetrical: the Sun in its circuit both appears and disappears. The Sun's Sign reflected as square, rhombus and a wheel since the Sun always rolls over the sky has gotten lots of extensions. The most common is the eight-pointed Sun, in which the rays symbolize eight times. The Sun's Sign with 12 rays directed to 4 sides symbolizes a year divided into 12 months. The Latvians have used the solar year as a measurement. The image related to the Sun's Way (Fig. 4a) is a personification of the Sun's rise and set (Fig. 4b). It also was called the Sun Tree (Fig. 5), World Bush, Little Oak Tree, Great Bush and Little Spruce. The Sun Tree called in other cultures also as the World Tree usually is an oak that symbolizes daily rhythm, the Sun's course and the World's order and reflects human preconceptions about the World (Fig. 6). Observing the Sun's course in the sky, annual celebrations have emerged. Rituals are performed, walking the Sun's direction (clockwise). The circle marks the demarcation idea of the internal and the external world, fight between light and darkness and defence of good (Celms, 2016). Religious ritual is connected by concepts of the Place, the Way and the Symbol.
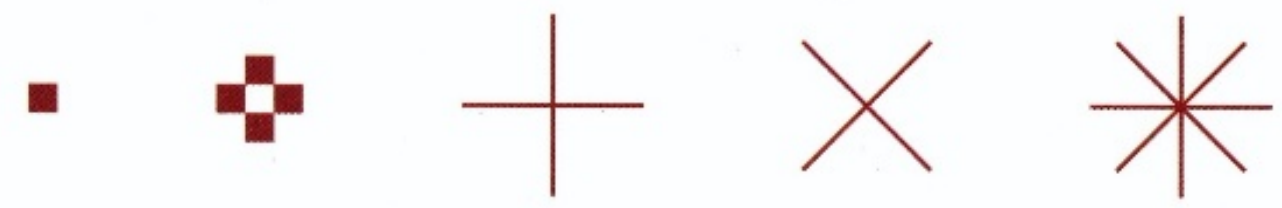

Figure 3 Crosses of stars: signs of the World's beginning and further development beginning or the centre, a cross with four branches, the straight cross, the slanted cross and the rotation or moving cross (Celms, 2016, 34) 


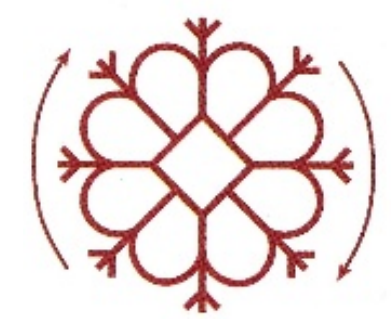

$\mathrm{a}$

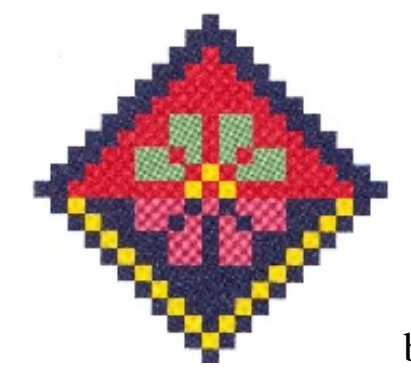

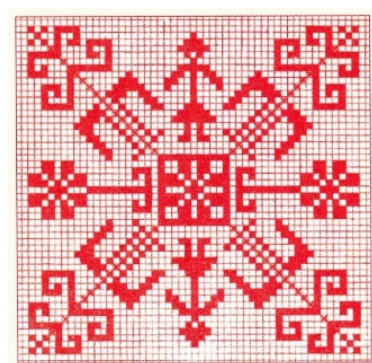

Figure 4 The Sun's movement: uphill, this Sun (on the top, a and b); in the centre (a and b), the Afterworld; downhill, the Underworld (at the bottom, $a$ and b) (Celms, 2016, 152)

Figure 5 The sign of Austra Tree also Solar Goddess Tree is a folklore image and Latvian sacred symbol

(https://i.pinimg.com/originals/ba/ff/e9/baffe9faadcaee043f3604e57b5214bc.jpg) Figure 6 Human, the Sun in the World's centre and the Sun Tree in a united World's model, the connection and dependence between nature and a man (Celms, 2016, 167)

Latvian ethnographic symbols represent the highest manifestation of God. The origin of all signs is the most diverse God's Crosses which start as dots in the centre and aspire for closing in the World's fabric grid. The first manifestation of God's presence in this World as a flash of light and a fair judge is the World's governor Thunder (Latvian: Pérkons) assigned by a military function. Allinclusive, impatient, direct, relentless, highly honoured, mighty and revered people's helper and unifier for collaboration develops the World created by God (Fig. 9), arranges basic forces, oversees and restores the Universe movement each time when it is under the threat to come to a halt or it has been taken over by darkness, cold, standstill and harmful forces. Whatever Thunder does, it is done in compliance with God's regulations and advice of advice. Due to God and Thunder's initial unity, the situation of self-initiative and self-organization is created: in the initial push, God's desire is expressed. God and Thunder start their dance - motion, from which time and the Universe as space starts (modern science in this regard puts forward a hypothesis for the Great explosion from which the Universe originated). Thunder strikes in the cross - in the centre of all events causes generative processes, brings into motion the Earth's fertility, initiates emergence of life, provides continuity of cosmic time flow and cyclic time flow in the Universe and arranges energies, principal elements of the World's creation. The principal form of Thunder's Cross (Fig. 7) which symbolized the Universe rotation is turning God's Cross and bending ends of its branches due to the rotation. Rays of light and space curve in the Universe. Our galaxy has got a form where at one end of the branch, there is the solar system with the planet Earth. The sign shows the centre (Fig. 8), unity of four, cycle of energy accumulation and discharge, eternal rotation - the Universe's breathing in and breathing out motion which has started in one direction that creates preconditions for motion in 
the other, opposite direction. A strong, popular sign all over the World is Firecross created from two crossed bolts of lightning which symbolizes light, life, fire (Fig. 10), attracts happiness and energy, protects from evil and undesirable natural phenomena. Relations between the human inner and the outer world are revealed in relationships between God and Thunder reflected as images of consciousness of the human individual "I" and the common "we". God is related to the consciousness of the individual "I" and is manifested in the soul link with the true "I" in the human. Thunder is in the link with the communality's "we" consciousness. The individual's personality consciousness is determined by integration into the human mutual relationship net up to expansion - in the nation (Celms, 2016).
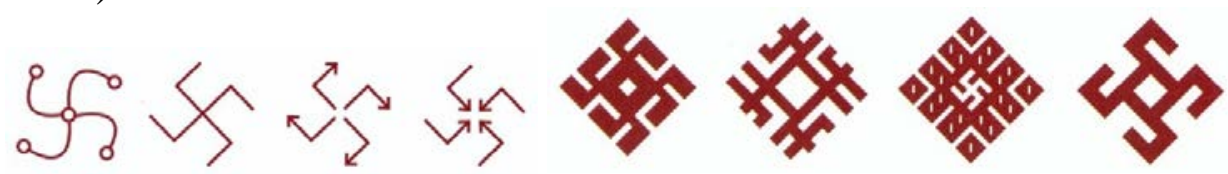

Figure 7 The principal form of Thunder's cross - ends of branches bending due to rotation of God's cross (Celms, 2016, 44)

Figure 8 Thunder or sky blacksmith's attributes: axes, the Sun and other images

(Celms, 2016, 50)

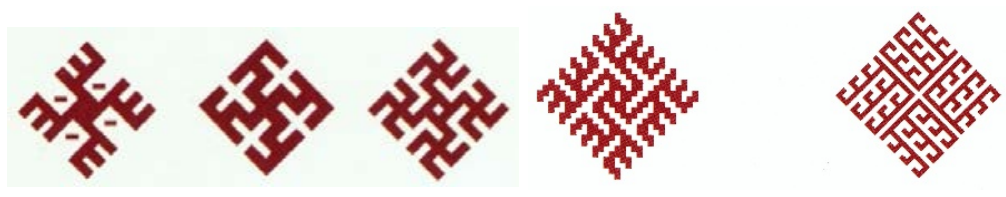

Figure 9 Thunder develops the World created by God and arranges the main principal elements and forces (Celms, 2016, 51)

Figure 10 Fire flames and whirls but always precisely in rhythm (Celms, 2016, 88)

God's daughter Fortune (Latvian: Laima) is the Goddess of destiny maker, giving life to people and nature, and happiness carrier related to birth and success. She decides upon people's destinies according to laws created by God. Fortune as the promulgator of the highest causal relationship laws decides whether the human will have a happy or unhappy life, compatibility with people and order of all matters, forges person's life activities and arranges events in life. Fortune spins, weaves and pulls the thread of life, health and welfare. The activity due to which so varied powers and events caused by them meet up and are twisted into a united thread of time and destiny (in a belt, rope, wreath, fabric or tangle) is symbolized by Fortune's Cross which is created rotating God's Cross and bending ends of its branches. Fortune's Cross symbolizes rotation and development of rhythmical and cyclic movement around the common centre of events. The World's different forces call events that come together in a single thread of time and destiny. The other Fortune's Sign is the Needle, the symbol of the World Tree, harmonizes 
relationships among people, helps not to give up circumstances, encourages purposefulness at work in order to obtain a lifelong fulfilment and defends from wrongdoers. The fir and pine needle design are considered as the symbol of health, fertility and long life. The Needle is like the footprints of Fortune. If one steps on them, the person's life becomes easier, happier. The way of life is daily care and rhythm. It is part of any happier life. Fortune shows a constant course of events, where moments of tension are equal by moments of relaxation - the same way as the day follows the night, work is followed up by relaxation. Thunder and Fortune manifested as compatibility and order of all matters, as rhythm, as the conformity of events work in a diverse area. They are closely knit together and represent a different scale of a common time flow, provide a course of time and determine or affect destiny. Thunder is the creator of the cosmic time cycle in the macrocosm, in the Universe of planets and stars. Fortune is the decision-maker of a person's life and destiny in the microcosm. However, it can also be shown as a lack of this conformity - in a disturbing course of events, destroyed rhythm, a tangle of different forces and an unfavourable decision. This coherence confirmed by the principal form is equal to Thunder's Cross (Fig. 11) which includes Fortune's Cross and four directions of the needle. All events in the World are arranged like on waves or hills: Fortune is sitting on a hill, Misfortune (Latvian: Nelaimīte) downhill. Fortune and Misfortune walk simultaneously along the same life footpaths. The middle between the top and bottom is the footbridge - the active threshold of balance between twists of life events that go up the hill or takedown. Creating and destroying forces, light and darkness meet on this border. The human being's task in life is to overcome this border and optional situation: getting over the footbridge means you have to overcome it and it brings you joy of living and wealth. Every person is the architect of one's own fortune and destiny. The Latvians do not look at destiny as unchangeable. The human being is given an opportunity to affect their destiny and sometimes even to change it essentially. In the World, everything is the sequence of phenomena whose real source is an accumulation of causes and conditions. The evergreen tree as spruce and pine is an eternal life's symbol, which in Fortune's whisk is manifested as a cyclic coherence: only the one who gets old and dies can get renewed (Celms, 2016).

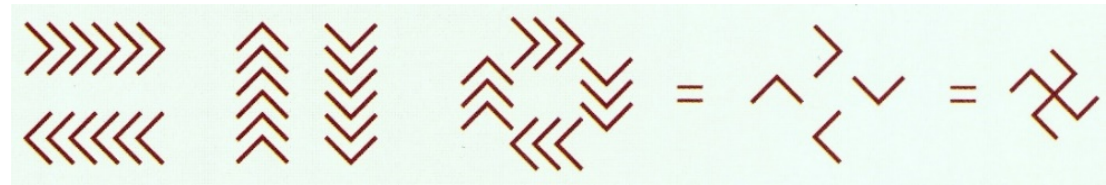

Figure 11 Thunder's Cross includes four directions of the Needle, Fortune's sign (Celms, 2016, 63) 
SOCIETY. INTEGRATION. EDUCATION

Proceedings of the International Scientific Conference. Volume IV, May $28^{\text {th }}-29^{\text {th }}$, 2021. 626-652

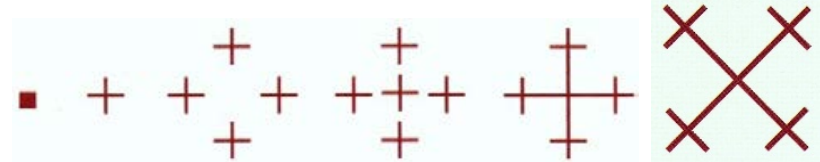

Figure 12 The dot, the little cross, a set of crosses and twofold is the cross of Mother Earth or Cross-cross (Celms, 2016, 96, 97)

God is the World's Father, but a feminine counterpart to God, the Goddess of the material world, women's defender Mother Earth (Latvian: Māra) is the World's Mother. Mothers are important in Latvian mythology deities. Mother Earth, known also as governor of the Land and the Underworld, Mother Forest, Wind, Sea, Milk, Cattle, Ghosts and Soul, symbolizes the border between this World and the Afterworld. She takes part in people's life activities, also in weddings when two (the male and the female) merge into one, creating a new wholeness. A linden tree is the symbol of a girl, but an oak tree - the symbol of a boy. Mother Earth has different kinds and several ways to exist and lots of varieties of the sign. All these signs present basic principles, security and relations between Heaven and natural powers. A combination of four crosses - the Crosscross is an enhancement of the simple cross which created a sign symbolizing the ruler of the material world. In comparison with God's Cross, ends of the Crosscross are crossed over. Their extension into infinity is interrupted with a little cross, which points to the limitedness and finitude of the material world in contrast to the infinity of the spiritual world. Material manifestations have the beginning and the end. The human being in this World is connected with birth when the soul embodies into the physical body and dying - death. Mother Earth's essence is twofold, and the Cross-cross can be looked in two positions of different meanings. The slanted Cross-cross (Fig. 12) symbolizes life creating and highday condition of the material world. Movement blossoms outwards - away from the sign's centre. The straight Cross-cross (Fig. 12) symbolizes the border between this World and the Underworld, where everything freezes, closing life borders in the World of four kinds - four cardinal directions, four seasons, four stages in life and the return of matter in its initial stage. The movement for crosses with life energy smothering character happens backwards to the sign's centre. Individually, the short-term essence of growth is emphasized. The Cross-cross can also be with smaller crosses and stripes. Mother Earth rules over life and no longer living. At the end of life, the human being finishes the course of life, and a body again gets into the Kingdom of Mother Earth. A human and plant are born from it and return to it. The Land is the Great Mother - holy, clear and fair. The symbol of Mother Earth is a straight, horizontal line, but the second symbol is a hook or triangle, whose 90-degree angle points downwards. Drawing the sign on a horizontal plane, sides are pointing to northwest and northeast directions, where the Sun sets during 
the Summer Solstice. The sign has a deeply symbolic purpose and power that opposes God's Triangle. Merging God and Mother signs, a rhombus is created to characterize balance and conformity. The pattern together with other signs creates a meaningful symbolism. Both of these signs, covering over each other, obtain a hexagonal star, also Bad Spirit's six-sided cross, which has a strong defence against evil. The sign of Mother Earth drawn as an equal triangle, a hook or halfcircle, with the top turned down, is related to symbolic roots and empowered with the opposite force of God's Sign. Mother of Water is symbolized by a zig-zag sign which reflects the river flow and plain of the land. God, Mother Earth and Fortune are invisible in Latvian godliness (Celms, 2016). In the Universe fourdimension space-time, Fortune represents the dimension of time - motion and events in time - and destiny, but Mother Earth represents three-dimension space, types, levels and forces of matter arrangement. God, Fortune and Mother Earth know the course of the following events.

Research problem: common and different features of the sacral space of the Latvians and other nations have been little studied. Research goal: analysis of the influence of the Latvian wisdom on traditions of the establishment of early places of worship. Research methods: analysis of archive documents and cartographic materials, study of published literature and inspection of sacral places in nature.

\section{Elements of Mythology and Cosmology in Ancient Housing and Shrine Design}

In the arrangement of signs related to the World's model (Fig. 6), the twin's principle is important - Father and Mother, spirit and matter, signs of World's wholeness and cyclic renewal for the horizontal division of the circle. Heaven and the Earth, and in nature existing relations of Cosmic forces marked along the vertical. The common understanding of the Indo-Europeans and the Balts about sacral space on the four-part horizontal structure of the Universe (cardinal directions) and the three-part vertical structure (Heaven-Earth-Underworld) is essential. The unity of a Men and Cosmos was confirmed by the comprehension typical to the Indo-Europeans and the Balts about a person's role in events of the Universe space-time. The World's structure formed by three vertically placed spheres was modelled as a tree in nature. A grand, impressive sign of the World Tree was created. In mythical World's centre between Heaven and Earth, between light and darkness and between the past and the future, there is the Man whose image is characterized by the vertical three-part division and the horizontal fourpart division, marking seven coordinates: the centre, top, bottom, north, east, south and west. The Man and the World Tree were revealed as symbols of the Universe structure, single motion and life - the World's axis, mediator between the Earth and Heaven. The flow of light never ends, but the World is infinite. 
Varieties of the symbolic meaning of the World Tree were characterized by a tree growing in several directions. At the World Tree, which gives people power and advice, protects the kin and the family, promotes the development and encourages to enhance and preserve moral values, the awareness of our past, present and future, our ancestors, children and ourselves is combined. This symbol shows an upwards aspiration of the World's order. The sign's simplest version reminds of a new tree that has just started branching, but in more magnificent derivations, the sign is as rich as its explanation. The Sun Tree as the compilation model of human knowledge and preconceptions is very diverse, but as an element of a peculiar pattern has similar motives in ornaments of other nations. In the Sun Tree, the human being's impression about the World is expressed: the roots were related to the Underworld, but the trunk represents the place where we reside together with animals and plants. The tree's foliage symbolizes the higher spiritual Heavenly World to which everybody aspires. Sun Tree's side branches are placed symmetrically to the middle part "grow" on slant upwards and downwards. The Sun sits on branches of the Light Tree. Upper branches help to stay up on the heavenly hill. Branches going downwards are not able to hold it - the Sun slides down the arms of the tree to continue circuit in the Underworld. The sign of this pattern integrates into the triangular platform whose top points downwards. Sometimes the platform of the Sun Tree is a square or rectangle. Candles are used to adorn the Sun Tree and also Needle and the Moon's Sign. The main stop point in the Universe space-time division is the Sun as a beautiful flower. Expansions of the pattern are shown as flowers - symbols of harmony and events in the Universe. Sometimes the treetop is emphasized. In other versions, the Sun or another element of the pattern is placed in extension of the middle part which is particularly magnificent, that is, the part of our life. The Sun Tree creates a diversified symbol and represents reaching upwards and growth and unites us with God (Celms, 2016).

In every historical period, buildings include elements related to the cosmos, and a man also created and arranged his dwelling as a small, symbolic territory of the Universe. People living in ancient times divine the Sun, the Moon, stars, birds, animals and plants. On the territory of Latvia, the oldest dwellings were conical tents covered with deerskin. An open fireplace was in the middle or in front of the room. The birch wood cards connected together at the top formed the frame of the home. Residents settled along the edge of the tent, and there were also belongings and food (Apals, 1996, 8). Later, dwellings were built more thoroughly from cards and twigs, which lower ends were inserted into the ground. A fireplace for cooking in the middle of the room gave light and warmth. The connection between the dwelling and the fireplace is shown in the sign of the hearth - a circle with a marked centre. The circle is considered to contain energy, forming a protective barrier to the sacred space, which provides protection from supernatural forces. 
Common characters of Indo-European and the Balts were included in the spatial composition of housing design - the rectangle or square with the highlighted centre. The Balts since $500 \mathrm{BC}$ have built for housing in-depth or surface structures of the oval or rectangular layout. The main room in the rectangular wooden house, covered by a two-pitched roof, was a common living room with a fireplace in the centre. The Balts and the Livonians received in the power of nature God's counsel for life and work, saw signs of the spirit world. Latvians used the power of signs to protect themselves, their families and their homes. A small cosmology in simple wooden dwellings can be read through several elements. In the Balts' tradition, symbolic interpretations of the square, including four seasons and four celestial meanings, were similar to the circle, expressing sacred time and space. Three gates mentioned for the Latvian farmstead also were given a beautiful symbolic meaning: one by the Sun, one by the Moon, by the third God came, every morning, every evening.

The oldest known holy place in the territory of Latvia has been found in the settlement of Sārnate bog: in the square, which is delimited by a fence, an image of an idol made of one tree was placed (Fig. 13) and a shrine was established (Apals, 1996, 21). In 1972 on the east coast of Lake Lazdiňš (Latvian: Lazdinu ezers also Lielais Lazdiñs), archaeologist, Honorary Doctor of the Latvian Academy of Sciences, Dr Hist. Jānis Apals (1930-2011) made archaeological excavations (Fig. 14) in Vaive Lazdini Hill (Latvian: Lazdinu uzkalniņ̌s) and revealed peculiar stone constructions as well as pits dug in the earth and filled with sand which was mixed with ash and small coal. On a small stone, there were iron artefacts - a socketed axe, chisel, two ends of a spear, scythe and awl fragments. Slightly further there was an iron knife with a bent back. On the northwest part of the hill, a quadrangular platform piled of rounded stones fit close inside the stone circle. On the platform three small fragments of a man's skull were found - from the facial part, top of the head and its base. The artefacts found in the middle of the hill date back to the $2^{\text {nd }}$ quarter of the $1^{\text {st }}$ millennium AD. In the Lazdini Hill, neither skeleton or cremation graves in the traditional form were found. Thus it is possible to consider that in these excavations Apals had found a possible ancient cult site (Apals, 1986). There are no recorded pieces of evidence about the site, however, geodesist, historian of geodesy and engineering education, Professor Jānis Klētnieks (1929-2021), based on archaeological excavations concluded that this was a cenotaph - an empty grave erected in honour of a leader whose remains are elsewhere. As it is said in a Latvian folk song, "Let my sword lie there instead of my bones." Apals has dated this unique place up to the $4^{\text {th }}$ century. Along the outer edge of a round hill, a horseshoe-shaped pile of stones was created in a northwest-southeast direction. On the south-eastern side of the stone circle, a break of up to 3 metres wide formed the first "gate" bounded on both sides by extra-large stones with a spike placed 
upwards or "gate posts". On the northeast side of the stone ring was a 1,6-metreswide second "gate", which was also bounded by large stones. A pit was dug in the centre of the hill, but another smaller pit opposite the second "gate" located in the northeast of the hill (Apals, 1996, 51).
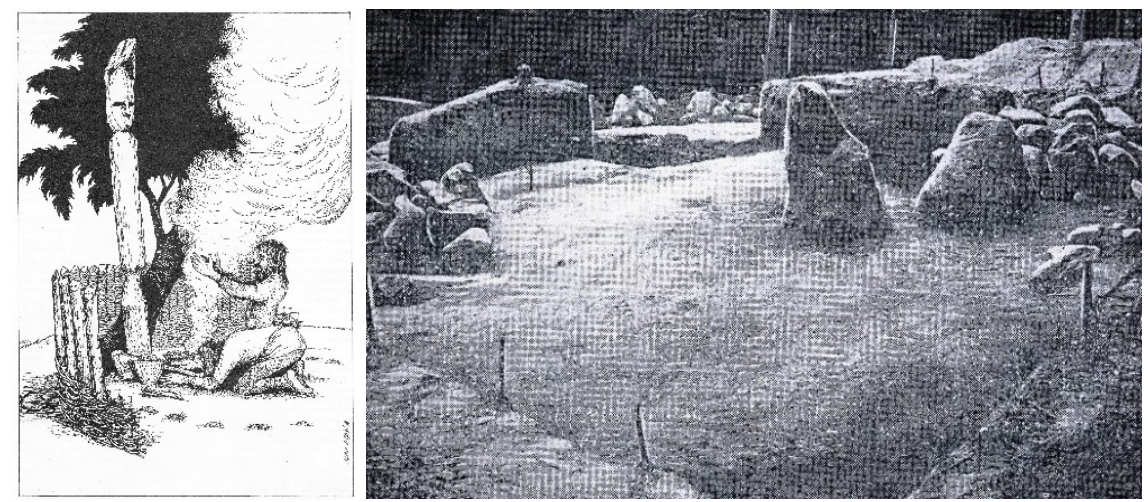

Figure 13 Artist Agris Liepiņš. Shrine with the image of an idol (Apals, 1996, 20) Figure 14 Peculiar stone structures uncovered during archaeological excavations in Vaive Lazdini Hill (https://www.senvietas.lv/wp-content/uploads/2019/12/1-lazdinu-uzkalnins-jkletnieks-705x469.jpg)

In Latvian mythology, a circle is the symbol of completeness, harmony and defence related to eternal, tireless motion, recurrence, return, cycle and wholeness. The circle contains energy, forms a barrier to protect the Sacred Space and symbolizes togetherness, unity, safety, light. In the design of the Balts' sacred sites, there was a circle (Fig. 15) or a square, which centre was marked by a stone focused on energy. Stone for modern man is just a building material, but people of ancient cultures had a different attitude and understanding of nature: such places were considered sacred, but the stone - as the "way" of life, through which received God's counsel and regained health. Positive energy is very well absorbed by water and concentrated by various elements as natural stones or man-made stone piles, tectonic elements as hills, valleys, terrain, crevices, caves and springs. Energy information of the Holy Stones can be read even after many centuries. Geologist, Doctor of Geological Sciences Rišards Griškjāns conducted a study on the energy structure of Latvia and concluded, that Latvia is a very energetic country, and it, like the human body, has its own energy-charged acupuncture points. Stones placed at specific locations on intersections of the earth's network of fine bio-energy streams are capable of radiating energy. In nature everything is interconnected, nature is alive and endowed with the soul. In Latvia, all sacred sites are energetically interconnected through energy information, astral and other fine matter fields, and there is an exchange of information between the holy places, where was not allowed to carry out an economic activity and nature were 
left untouched. Ancient Latvian sacred activities of fertility cult took place in the open air under the open sky. Good energy concentrates in woods, in the countryside, in dry areas where grass grows. People donations and prayers gathered in sacred sites - at the tops of sacred places named Elka Hills and in meadows, sacred groves, at holy trees, big stones and piles of stones, as well as at excellent waters that have been attributed to the healing power. They held trees and groves sacred because believed, that life forces, spirits of nature and goddesses live there. The main holiness in the grove was a particularly large tree, where the voice of the deity was heard. Tree growth is a sign of an energetic place, and for a modern person, it can be as a connection to nature. If the person is tired, exhausted, he does not have to go looking for the strongest energetic places to restore them. It is enough if he can relax for a moment in nature and take a deep breath of fresh air. The person, receiving energy, feels the heat and lightness takes over. The head becomes clearer.

The Tuareg people, a large Berber ethnic confederation, principally inhabit the Sahara in a vast area, are well known for their nomadic architecture (tents). The rectangular tent does not need any crossbeams and has a high mullion. Three to five slanted posts, which are anchored on the outside, form the four sides. The tent is traditionally constructed for the first time during the marriage ceremony and is considered to be under the ownership of a married woman. In Tuareg society, women are respected. Sedentary dwellings generally belong to men, reflecting a patriarchal shift in power dynamics. Current documentation suggests a negotiation of common practice in which a woman's tent is set up in the courtyard of her husband's house. It has been suggested that the traditional tent construction and arrangement of living space within it represent a microcosm of the greater world as an aide in the organization of lived experiences.

M. Phil, S. M. Arch. S. and Arch. Dr. Nicolas Reeves from École de Design, Université du Québec a Montréal, Canada, consider that an eloquent example can be found in the Tuareg tent, one of the simplest houses of all (Reeves, 2017). The tent is the centre of the world of work for the nomad woman. The furnishing of tents is an individual process, but the orientation of four celestial sides is taken into account. The tents remain similar in their basic structure. The areas facing the four sides of the tent have different significations, and equipment is rational. The place for receptions is in the western area, where the entrance is open to the World. The right part of the tent is assigned to the wife. The southern area is beneficial, and children normally sleep on the floor. The kitchen is in the front. The northern area is the man's area. The left part is seen as the evil one. Here he stores all the tools he needs for his work. The married couple sleeps in the left part. Their heads are always pointing south as does the main opening of the tent that is usually kept open. The only blind side of the tent on the eastern area is dedicated to prayer. The fireplace is the central part of the living space. The fire isn't just used for 
cooking but it is the source of light, the heating and the place where guests are welcomed. The fireplace has to be treated with respect at all times. The link between cosmos and architecture unfolds on symbolical and analogical levels.

In cosmology, a branch of science that studies evolution and the structure of the Universe, historically, the Greek worldview has existed for the longest time. Ancient Greek cosmology placed man and his world at the centre of the spherical layers of the sky, and man's relationship with space was reflected in the concept of temple proportions and planning: the most sacred place was in the centre of the cult building. In Ancient Greece, Delphi considered the centre of the World was famous with the sanctuary of Athena Pronaia (Fig. 16) built between 380 and 360 BC. This circular temple (tholos) differs from a circular colonnade (monopteros) without walls needed to build a domed cella. A stepped podium as elevation without any walls was developed into a sacred place for communicating with God and became the symbol for contact beyond the realms of people's imagination. The circular temple in Delphi was surrounded by a colonnade of Doric columns. The circular wall of the sanctuary supported the marble dome to create a space, where inside a stone bench was placed in the centre. In ancient Greek architecture, a rectangular temple remains the same even in the case of a circular temple surrounded by a colonnade and can be seen as a topological inversion of the cosmos. The Greeks considered that the earth was flat and in its centre was Delphi, where they built the first temple dedicated to God of brihgt light Apollo. In the middle of the Temple of Apollo, which dates to the $4^{\text {th }}$ century $\mathrm{BC}$, the oval white stone was considered the navel of the World. The Temple of Apollo was known as the Holy Territory and the centre of the complex, from which the Holy Way led to the Agora or market square. The road from the Temple of Apollo led southeast to the sanctuary of Athena Pronaia.
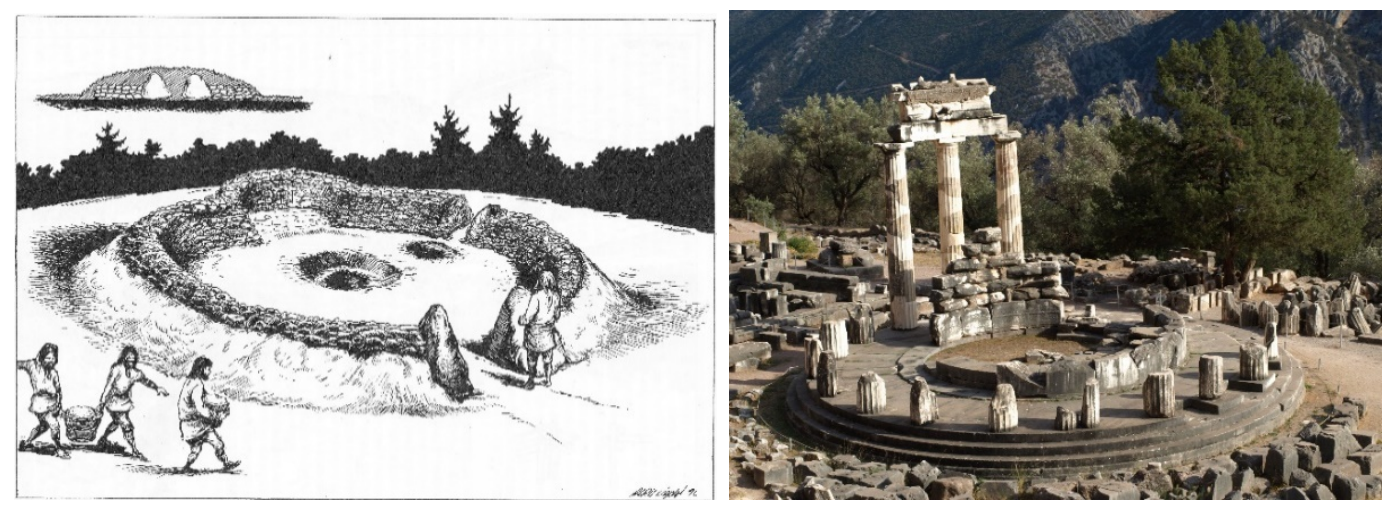

Figure 15 Artist Agris Liepiňs. The centric sacred site of the Balts (Apals, 1996, 50) Figure 16 Ruins of circular Delphi Tholos (online 28.02.2020, source https://i.pinimg.com/originals/48/6a/a9/486aa933a15b8d27da035ad6c3af06c5.jpg) 


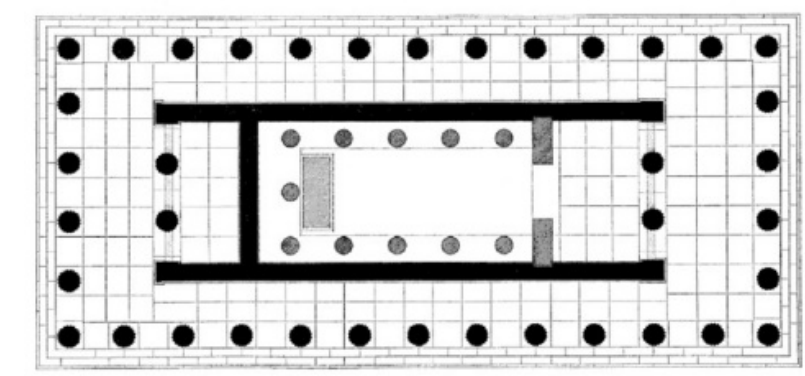

Figure 17 Plan of the Temple of Hephaestus (online 28.02.2020, source https://interactiveancients.files.wordpress.com/2012/09/hephaestion.jpg)

On top of the Agoraios Kolonos Hill at the north-west side of the Agora of Athens, the Temple of Hephaestus or Hephaisteion (Fig. 17) inaugurated in 416415 BC was dedicated to Hephaestus, the ancient Greek god of fire, and Athena, goddess of pottery and crafts. This classic example of Dorian architecture designed by Iktinus, one of the talented architects who also worked on Parthenon, is the best-preserved ancient Greek temple in the world. It has the inner area of the portico (pronaos), situated between the portico's colonnade and the entrance to the cella (from Latin for small chamber), the centrally enclosed cella surrounded by columns of this peripheral temple and housing cult images at the centre of the structure and the inner shrine (opisthodomos). The temple from the $7^{\text {th }}$ century until 1834 served as the Christian church dedicated to Saint George Akamates. Researcher of Greek monuments in a wide, universal cultural context, French architect, archaeologist Julien-David Le Roy (1724-1803), stood opinion that architecture always follows the evolution of the society. His book dedicated to ruins of the Most Beautiful Monuments of Greece had a greater impact on practical architecture. Le Roy was elected a member of the Royal Academy of Architecture, and in 1762, he was appointed official historian to the Academy. Besides other works, he wrote a treatise on the evolution of Christian temples from Constantine the Great to the contemporary era. After this second edition (Le Roy, 1770) was released, Le Roy's work greatly influenced the art and architecture of his time. From then onwards, all artistic and architectural creations were marked by the aspiration to return to the perfection of ancient Greek art. This work was released at the time when prominent scholar, a German art historian and archaeologist Johann Joachim Winckelmann (1717-1768) spoke of the supreme humanism of the Greek and the aesthetic ideal expressed in ancient Greek art, the same time when the European public had started to idealize antiquity. 


\section{The Creating of Sacral Space at the Origin of Christianity}

In Rome on one of the hills, the construction of majestic buildings began from 46. Under the Roman Emperor (98-117) Marcus Ulpius Nerva Traianus's guidance of the political, administrative and religious centre of symmetric layout, Forum Traiani (Italian: Fordo di Traiano; 112) surrounded by a covered gallery (Latin: porticus) was built in compliance with Apollodorus Damascenus (50/60130) design. In the complex of monumental buildings (107-113), the Temple of Trajan (Italian: tempio del divo Traiano) was included. The Roman Emperor (27 BC-14 AD) Gaius Octavius achieved the title Augustus meant the "holy" built a double-level Domus Augusti - the first biggest building on the Palatine Hill, on which southeast side there was the first Roman ruler's residence Casa Romuli and sacred sites that related to the foundation of Rome. The third Roman Emperor (37-41) Gaius Iulius Caesar erected a palace, and a wooden bridge joined it by the Roman Forum to extend the building to the northwest. The Roman Emperor (81-96) Titus Flavius Domitianus on the Palatine Hill built the main Emperors' residence up to the fall of the Empire - a tripartite Domitian's Palace designed by architect Rabirius. There was a wide one-way door at the façade by a frontal portico. The chancel situated next to Aula Regia. The Emperor and his advisers made administrative and political decisions in the central nave (French: nef, Latin: navis) of the basilica turned towards the Clivus Palatinus which formed processional route issues off the Sacred Road (Latin: Via Sacra) (Fig. 18) and runs up onto the Palatine, where it disappears. It probably ran as far as the Domus Augustana. The Sacred Road was the main street of ancient Rome, leading from the top of the Capitoline Hill, through some of the most important religious sites of the Forum where it is the widest street, to the Colosseum. The road was part of the traditional route of the Roman Triumph that began on the outskirts of the city and proceeded through the Roman Forum. In the fifth century BC, the road was supported by a super-structure to protect it from the rain. During the reign (5468) of the Roman Emperor Nero, it was lined with colonnades. The road provided the setting for many deeds and misdeeds of Rome's history, the solemn religious festivals, magnificent triumphs of victorious generals and the daily throng assembling in the Basilicas to chat, throw dice, engage in business or secure justice. While the western stretch of the Sacred Road which runs through the Forum follows the original ancient route of the road, the eastern stretch between the end of the Forum and the Colosseum is a redirection of the road built after the Great Fire of Rome. 


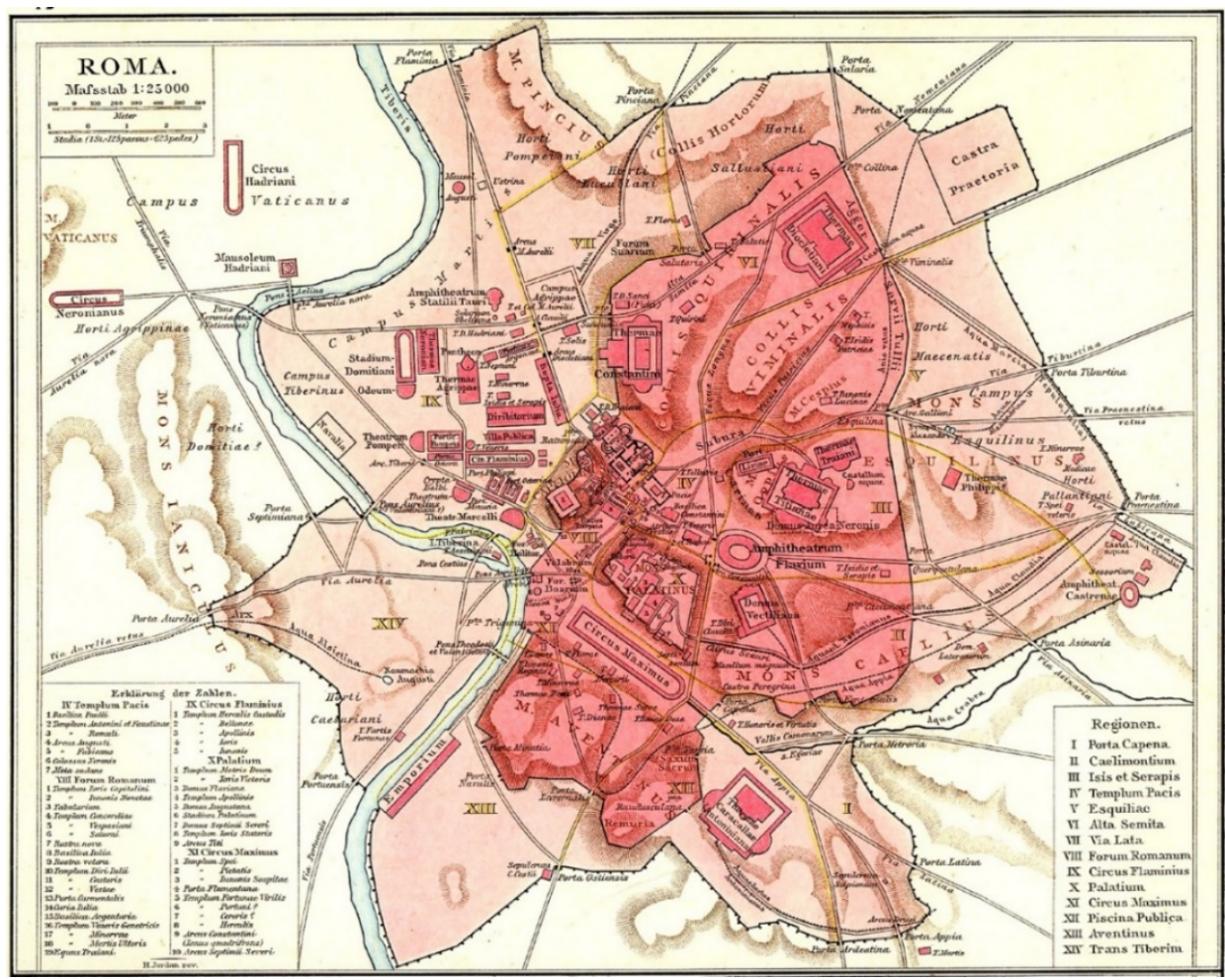

Figure 18 Jordan H. Map of ancient Rome City. 1886 (Jordan, 1886)

The Emperor of the Roman Empire (Latin: Imperatores Romani; 306-337) Constantine the Great (Latin: Constantinus I Magnus) being aware of the significance of Christianity acknowledged himself as a Christian. Using Caracalla and Diocletian's therms as samples, in Rome, the three-nave Basilica of Maxentius and Constantine (Latin: Basilica Constantini, Basilica Maxentii; 308312) covered with a vault was built instead of a big warehouse (Latin: horrea piperataria). Constantine I gave Roman Bishop the Lateran Palace (Latin: Palatium Apostolicum Lateranense) as a gift so that Popes would have a home. On the Caelian Hill, in 313 the construction of the most ancient Roman cathedral the Cathedral of the Most Holy Saviour and of Saints John the Baptist or the Archbasilica of St. John in Lateran (Latin: Archibasilica Sanctissimi Salvatoris; 324, rebuilt after 430) - began. The Archbasilica and the Bishop's residence were included in the perimeter building. Constantine I in 326 proclaimed Christianity as the only religion in the Roman Empire. The Archbasilica of St. John in Lateran is the World's and Roman cathedral.

Catholic tradition holds that Peter, after a ministry of 34 years, travelled to Rome and met his martyrdom there along with Paul on 13 October 64. His execution was one of the many martyrdoms of Christians following the Great Fire of Rome. According to Origen, Peter was crucified head downwards, by his own request because he considered himself unworthy to die in the same manner as 
Jesus. The crucifixion took place near an ancient Egyptian obelisk in the Circus of Nero. The obelisk now stands in St. Peter's Square and is revered as a "witness" to Peter's death. According to tradition, Peter's remains were buried just outside the Circus of Nero, on the Mons Vaticanus across the Via Cornelia from the Circus. The road Via Cornelia ran east to west along the north wall of the Circus on land now covered by the southern portions of the Basilica and St. Peter's Square. Almost 300 years later, Papal Basilica of St. Peter (Latin: Basilica Vaticana, Basilica Sancti Petri) built by Constantine I between 319 and 333 over this site was of typical basilical form. A wide nave and two aisles on each side and an apsidal end, with the addition of a transept as a perpendicular volume to the longitudinal axis, giving the building the shape of a cross over 103,6 metres long. The entrance was preceded by a large collonaded atrium by a fountain. The Basilica had been built over the small shrine believed to mark the burial place of St. Peter, though the tomb was "smashed" in 846. The area now covered by the Vatican City (Latin: Status Civitatis Vaticanę) had been a cemetery for some years before the Circus of Nero was built. Like all of the earliest churches in Rome, both this church and its successor had the entrance to the east and the apse at the west end of the building. In the hall, the altar situated in front of the semi-circular apse. The entrance in the atrium took a long wide stair and through the triumphal arch. Since the construction of the current basilica, the name Old St. Peter's Basilica has been used for its predecessor to distinguish two buildings (Fig. 19).

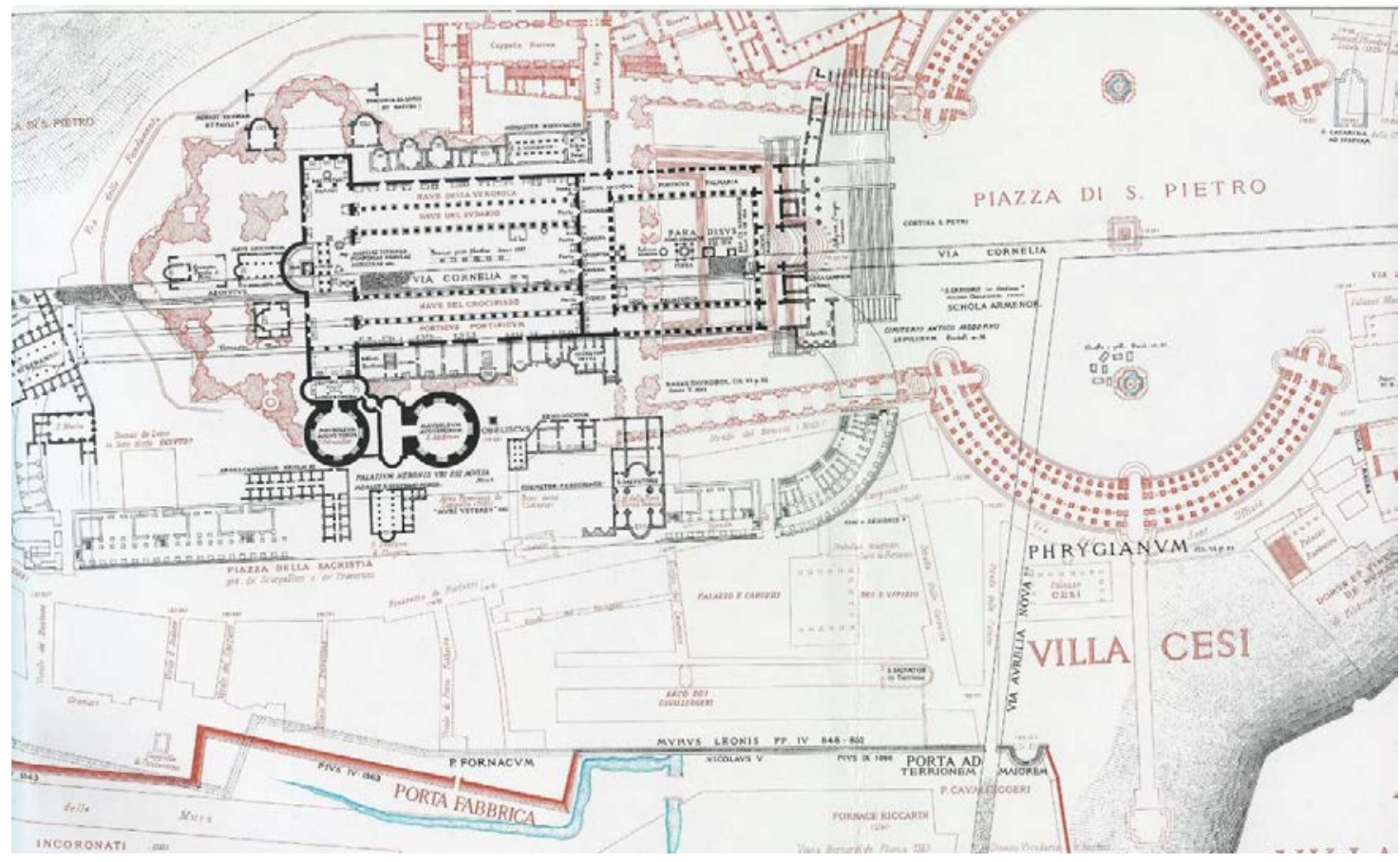

Figure 19 Archaeologist, professor at the Rome University, Rodolfo Amedeo Lanciani (1845-1929). A fragment of the map of Rome with Old St. Peter's Basilica built by Constantine I between 319 and 333 (Lanciani, 1893-1901) 
Basilicas built by Constantine I and his descendants became predecessors of cathedrals used until the fourteenth century for religious and social activities. During the first centuries of Christianity, deep in the apse of early basilicas, the bishop's throne or cathedra (Latin: Cathedra, Greek: Kathedra - "desk”) was placed. In the basilica by the cathedra (German: Kathedralkirche, Kirche der Kathedra, Latin: ecclesia cathedralis), or in the cathedral (German: Kathedrale or Dome), the Holy Court, philosophical contemplations took place, and political issues were discussed, but the metropolitan governed the metropolis; archbishop, the archdioceses; and bishop, the bishopric. In the basilica considered as a privileged building, miraculous icons and Saints' relics were placed to be lionized by pilgrims who worshipped Jesus Christ and His mother the Virgin Mary. Initially, Roman emperors did not allow Christians to build basilicas in the city, thus obtaining the name "outside the walls". Pope (352-366) Liberius built the three-nave St. Mary Major Basilica (Italian: Basilica di Santa Maria Maggiore; founded in 356) where the relic of the Bethlehem's Manger is. Western Roman Emperor (393-423) Flavius Honorius Augustus financed building of the Papal Basilica of St. Paul outside the Walls (Italian: Basilica Papale di San Paolo Fuori le Mura; around 370) where St. Paul's grave is. All four basilicas situated in Rome obtained the honorary title Basilica majoris and privileges. In the Roman Catholic Church, there is a distinction between Basilica majoris and Basilica minoris, which are honorary titles awarded by the Roman Pope. Basilicas minoris is located in different cities. In the Western or Roman Catholic Church, Rome became the Christianity centre by cult buildings and sacral sites. Italian architect, Professor Celestino Soddu considers that the city is a collective dream performed by a growing toward an idea of future. It's made by different and unpredictable events carried out by different ideas during the time. The beauty of historical cities in their wonderful results springs out where we can appreciate the memory of multiple and different interpretations recognizing their own identities. Beauty is in the continuous transformation of the past into the future (Soddu, 2016).

During the fourth century, Christians created places of worship, where the altar was disposed. Unlikely the pagans, Christians did not consider the temple as God's home but rather a believers' gathering place in which spatial solution appropriate for the function is initially not related to symbolism. Large-size public buildings of elongated planning - basilicas built by Romans for court sessions, meetings and trade - were adapted to cult needs. Windows built at the top of walls illuminated the worship hall divided lengthwise into three or five naves with the help of columns or pillars. The middle nave was higher and wider. One semicircular planning niche or apse created in the eastern part of the worship hall was just opposite the main entrance in the building's western part, where narthex or a closed anteroom separated by a wall was created for the people who are not allowed to go in the worship hall. Sacral buildings of simple layout consisted of 
two big zones: the presbyterium, where the sacred ritual took place, and the worship hall. Stairs were built in front of the main entrance. Christians changed the architecture of basilicas according to the ritual and created symbolism for religion. In the Roman Empire, there were public buildings - basilicas and sacral buildings - and basilicas with a naturally illuminated rectangular atrium.

Traffic in the seas contributed to the creation of craft and merchant cities, market places and ports. At the Bosphorus exit in the Marmara Sea, Europe borders Asia, and the deep bay of the Golden Horn (Latin: Sinus Ceratinus) separates the peninsula on which Constantine I instead ruins the Aphrodite Temple of the Greeks built the Church of St. Irene (Hagia Irene/Eirene; burnt down in 532) covered with a cupola. The atrium located in front of the entrance of the church of Greek cross layout. Trading and emperors' ceremonial events took place on the main forum Augusteion surrounded by the portico. Near the university, library, Senate building, Archbishop's Castle, eparch's praetorium and sellers' sheds. On the Augusteion's north side, where the Acropolis is situated, the main church St. Sophia's Basilica (Latin: Magna Ecclesia; 324-337) covered with a wooden roof and the atrium in front of the entrance was built. On the south side, Byzantine emperors' main residence (330-1081) the Great or Holy Palace (Latin: Palatium Magnum, Sacrum Palatium) is located on the tip of the cape. The Constantinian Wall (around 320) built on the west side created a strongly fortified city of the triple layout. The Byzantine emperors' ceremonial procession road is covered with stone slabs - Mese (Latin: Media - "the middle street") - which started from the Augusteion, and functionally different forums determined the composition of planning (Fig. 20). On the hill near the Constantinian Wall, the Church of the Holy Apostles (Italian: chiesa dei Santi Apostoli; around 330, destroyed in 1461) of Greek cross planning, covered with a golden roof and cupola, was built for Byzantine emperors' burials. Roman Emperor (324-361) Flavius Julius Constantius II completed the construction of this building by façades of colourful stone, and he also built St. Sophia's Basilica (burnt down on 20 June 404) consecrated on 15 February 360. The Byzantium capital city Constantinople (330-395) called as "the Second Rome" solemnly founded on 11 May 330 became the Christianity centre of the Eastern Orthodox Church with sacral sites where building traditions of cult structures developed. As the largest and wealthiest city in Europe during the fourth to thirteenth centuries and a centre of culture and education, Constantinople came to be known by prestigious titles such as Basileuousa (Queen of Cities) and Megalopolis (the Great City) and was, in colloquial speech, commonly referred to as just polis "the city" by Constantinopolitans and provincial Byzantines alike. 


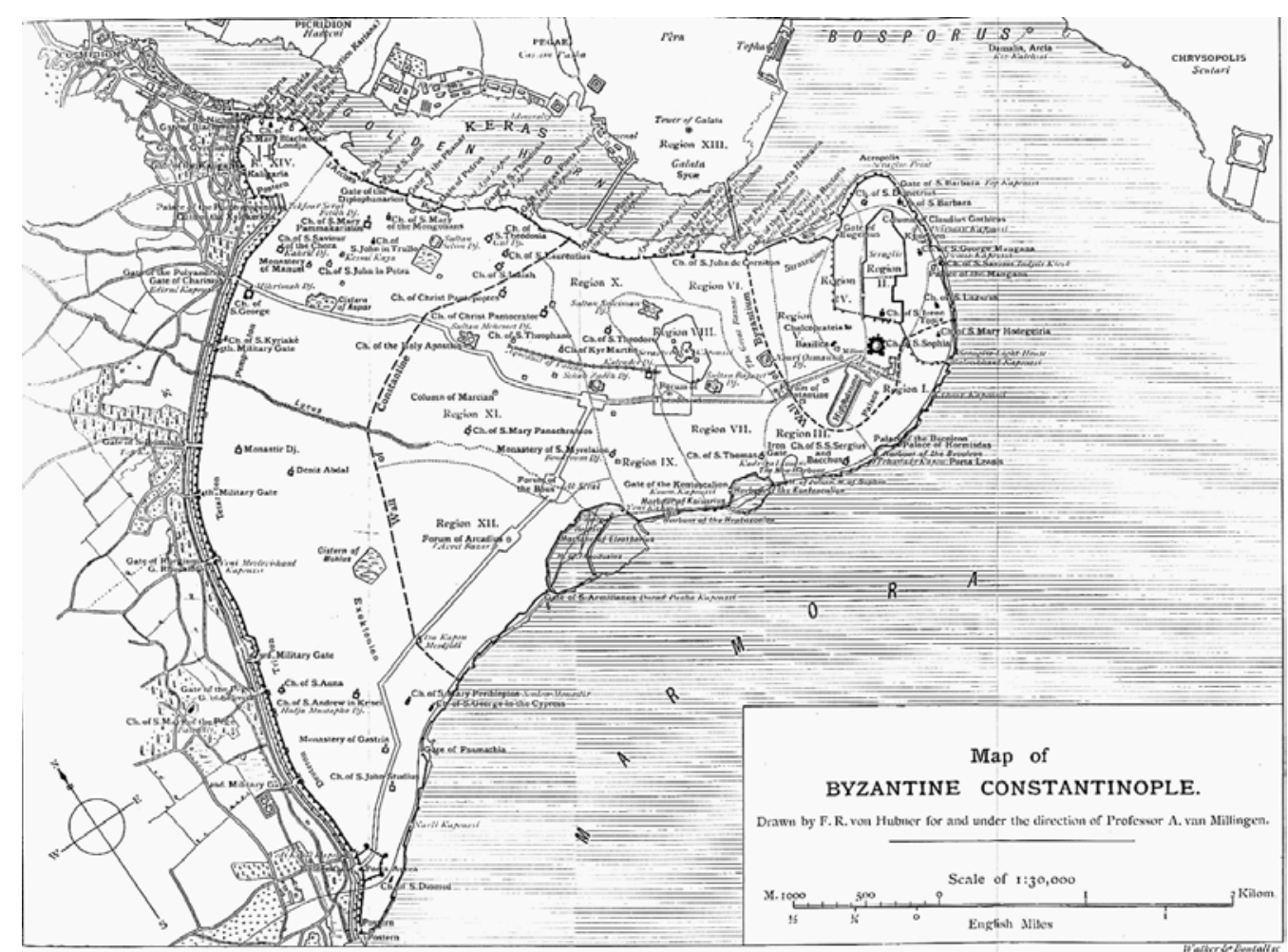

Figure 20 Professor Alexander van Millingen (1840-1915), drawn by F. R. von Hubner. Map of Byzantine Constantinople. 1899 (Hubner, 1899)

The former Greek Orthodox Christian patriarchal cathedral Hagia Sophia (Latin: Sancta Sophia or Sancta Sapientia), built at the beginning of the Middle Ages, was the world's largest building famous in particular for its massive dome (Fig. 21) and an engineering marvel of its time. It is considered the epitome of Byzantine architecture and is said to have "changed the history of architecture". The Hagia Sophia designed by the Greek geometers Isidore of Miletus and Anthemius of Tralles was originally constructed as a cathedral between 532 and 537 on the orders of the Byzantine Emperor Justinian I to occupy the site, the prior one having been destroyed by rioters in the Nika Revolt. The cathedral was dedicated to the Wisdom of God, the Logos, the second person of the Trinity, its patronal feast taking place on 25 December and the commemoration of the birth of the incarnation of the Logos in Christ. Although sometimes referred to as Sancta Sophia (as though it were named after Sophia the Martyr), sophia being the phonetic spelling in Latin of the Greek word for wisdom, its full name is "Shrine of the Holy Wisdom of God". From the date of its construction's completion in 537 until 1453, it served as an Eastern Orthodox cathedral and the seat of the Ecumenical Patriarch of Constantinople, except between 1204 and 1261, when it was converted by the Fourth Crusaders to a Roman Catholic cathedral under the Latin Empire. 
Constantinople, where the Sacral Way determined the planning of the Sacral Place, became an example for creating of sacral urban space in the Eastern Orthodox Church that joined Slavs in Kievan Rus' (Latin: Russia, Ruthenia, Russian: Киевская Русь, in Viking languages: Garðaríki, Old Slavic: Poу́́cb; around 860-1132/1240) adopting Christianity in the tenth century. Italian architect, Professor Enrica Colabella, considers that city structure by a perfect correspondence between urban space and the world of signs resembles language. A correspondence between streets, buildings and squares on one side and phonological, syntactic and semantic elements on the other. This process is like the crossing of a river that is running towards the sea connecting its two different sides with all the memory of its own running in the swimmer crossing (Colabella, 2017). An Austrian-British philosopher Ludwig Josef Johann Wittgenstein (1889-1951) believed that Philosophy of Language may investigate relations between language, language users and the World. Our language can be considered as an old city: a maze of streets and squares, old and new houses and houses with parts added at different times. All this surrounded by a network of new suburbs with straight and regular streets and uniform houses.

Outside the walls of Jerusalem, Golgotha or the Skull Place (Latin: Calvary) and possible Christ's punishment site are located. According to the instruction of Constantine's the Great mother Flavia Iulia Helena Augusta (around 250-330), the Church of the Anastasis (German: Auferstehungskirche; 325/326-335, destroyed in 1009) called the Church of the Holy Sepulchre (Latin: ecclesia Sancti Sepulchri, German: Grabeskirche, Kirche des Heiligen Grabes, Russian: Воздви́жение Честно́го и Животворя́щего Креста́ Госпо́дня) or the Church of the Resurrection was built. High walls of the Anastasis Rotunda supported the dome in the central part of the five-aisled basilica. The Church of the Anastasis complemented around 330 by a belfry was solemnly consecrated on 14 September 335. As toward the east the Temple Mount blocked the Decumanus Maximus orientated the eastwest direction, therefore the second main road pair over the Cardo subordinated to the planning along the Tyropoeon Valley. The Decumanus in the north of the Temple Mount was created. The Cardo Maximus, orientated in the northsouth direction, reached in the fifth century the $21 \mathrm{~m}$ width, became the centre of economic life and finished at the Roman garrison camp where in the right angle, it crossed the Decumanus Maximus (Fig. 23). The Cardo Maximus formed a link between the New Church (Nea Ekklesia; 543) and. During the Second Crusade (1147-1149), knights rebuilt the Church of the Anastasis, the most important holy site for Christians: the façade by the main entrance gate, in front of which the atrium surrounded by chapels was turned towards the Cardo Maximus. Opposite the belfry (architect Maitre Jourdain; 1160-1180) completed in 1172, it takes 12 steps in order to go upstairs to a separate Crusaders' ceremonial entrance into Golgotha. There are 14 meditations, stations or stopping 
places on the Way of the Cross (Fig. 24). Reconstructed Church of the Anastasis was solemnly consecrated on 15 July 1149. At the east end of the main temple Catholicum (German: Katholikon; 1160-1170) of the Church of the Anastasis complex (Fig. 22), a passage was made to a circular gallery. In the north gallery of Catholicum, huge square buttresses and high vaults form the Arches of the Virgin Mary, which in the east is closed by the Holy Prison. The crown of three chapels for secondary worship places consists of the Loginus Chapel with the Altar of the Roman Army Commander (Latin: centurio), martyr St. Loginus (German: Kapelle des St. Longinus), Division of Holy Robes Chapel and, on the right, the Greek Chapel of the Derision from which steep steps descend to the underground Armenian Chapel of St. Helen (German: St. Helena-Kapelle) whose official name is the Chapel of Holy Cross (German: Kreuzauffindungskapelle). This was the crypt of Emperor Constantine's basilica (fourth century). The main altar was erected for St. Helena and Gregory the Illuminator. A steep staircase leads to the Franciscan Chapel of the Finding of the Cross (Inventio Crucis) where, according to tradition, St. Helena discovered the True Cross. The Franciscan Monastery has been added to the north part of the temple's complex. The Franciscan Church was made. Jerusalem became the world's sacral centre which consists of all types of sacred buildings and the Cross Way.
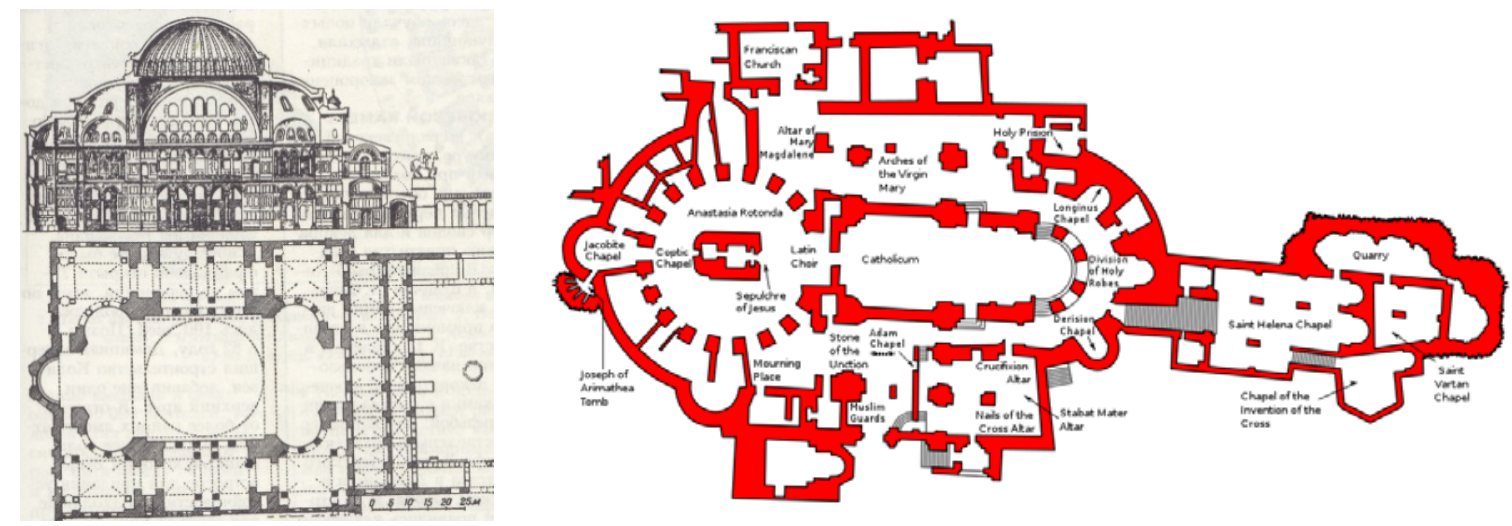

Figure 21 Anthemius of Tralles, Isidore of Miletus. The longitudinal section of the The Hagia Sophia (532-537) and a plan with the atrium, outer and inner narthex (Adamchik, 2005, 233)

Figure 22 Plan of the church of the resurrection building complex in Jerusalem (online 07.05.2019, source:

https://upload.wikimedia.org/wikipedia/commons/thumb/5/53/Anastasia_Rotonda_sketch_1.s vg/1000px-Anastasia_Rotonda_sketch_1.svg.png)

Until 4 July 1187, Jerusalem was ruled by knights. During the Third Crusade (1189-1192), knights, monks and merchants from Lübeck and Bremen the “St. Mary's Teutonic Brotherhood in Jerusalem” on 6 February 1191 confirmed. Later the Ordo domus Sanctae Mariae Teutonicorum in Jerusalem (German: 
Brüder und Schwestern vom Deutschen Haus Sankt Mariens in Jerusalem, in short, Deutsche Orden; 1198-1525) or the Teutonic Order was made. German merchants started to monitor traffic on important earth highways, waterways in rivers and seas in Europe, expanded the impact in the Baltic Sea region to spread Christianity under the leadership of the Pope and the Holy Roman Emperor.
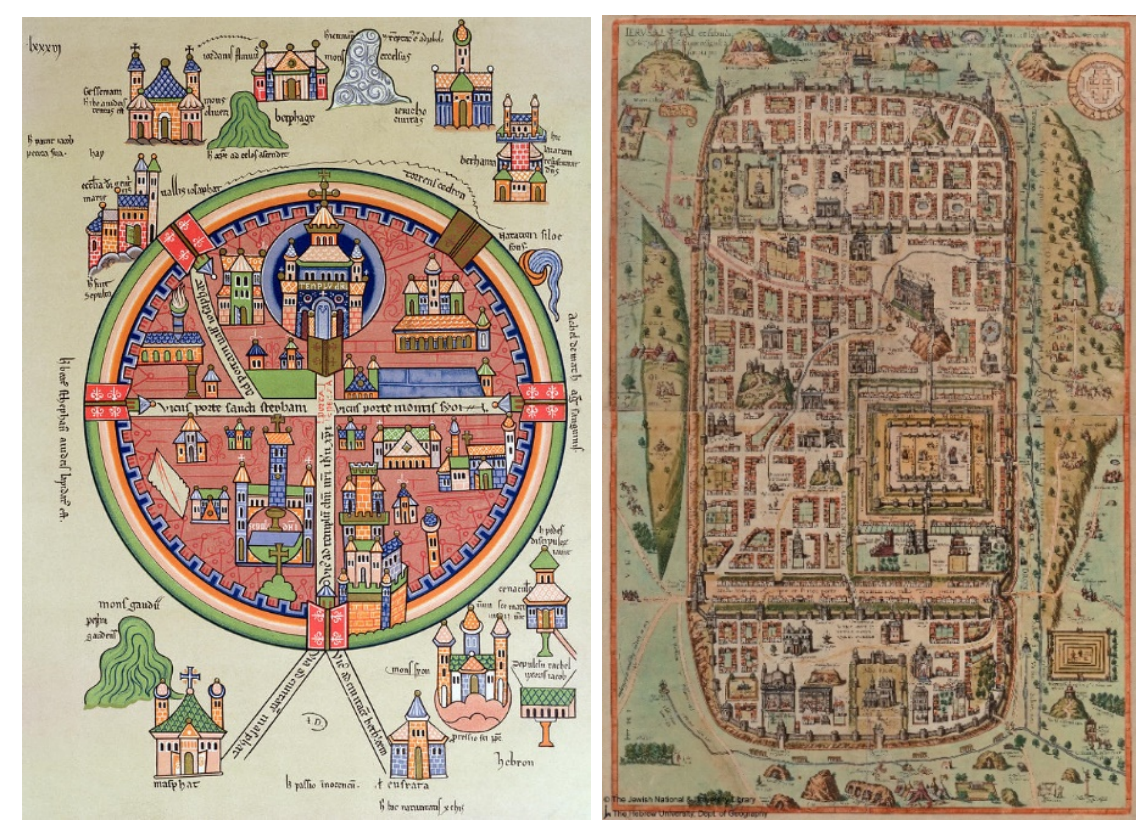

Figure 23 French school. A drawing (colour litho) of an ancient schematic map of Jerusalem and Palestine with the sacred sites and the Temple of Solomon. 19th century (online 07.05.2019, source: https://fineartamerica.com/featured/ancient-map-of-jerusalemand-palestine-french-school.html)

Figure 24 Imaginary plan of ancient Jerusalem and its suburbs at the time of Jesus. 1590 (IERVSALEM, et Suburbia eius, sicut Tempore Christi Floruit, cum Locis, in quibus Christ

Passus. Decripta per Christianum Adrichom Delphum. 1590, The Jewish National \& University Library. The Hebrew University, Department of Geography, online 07.05.2019, source: blob:null/1851cb49-3986-4c07-ba1b-bbb2faadeedb)

Christians created functionally diverse types of sacred buildings whose design, structural structure and choice of architectural elements subordinated to the needs of the creation of the sacred resting place, the religious ritual and pilgrims. During the course of centuries, the complex of the Church of the Anastasis around the rotunda has been rebuilt and supplemented by different sacral elements. The mutual placement of the cathedral, churches, chapels and belfry creates a very complex structure. Cult buildings of the Greek and Latin cross layout were involved in the urban environment. Three major Christian centres created at Rome, Constantinople and Jerusalem influenced the development of urban planning in Europe. 


\section{Conclusions}

1. Geometric signs of strong energy embody rhythms of nature, but symbols characterize the special relation to nature, the World and the Universe. The unity of the person and nature (cosmic) run covers the potential of harmony to restore the lost balance in the modern physical and spiritual world. Christians created symbolism for religion and places of worship, where disposed the altar according to the ritual.

2. Representatives of ancient civilizations maintained a special connection with nature and the Universe and believed that God brought blessings to the earth and people and developed the World, so they established shrines for communication with God. Religious rituals of the Balts' tribes took place in energetically powerful sites in nature near their places of residence. The layout of the ancient Latvian places of worship on hills was formed by a circle - a strictly geometric and symmetrical sign, which in the language of symbolic signs indicates a person's connection with God and the Universe. The Tuareg tent can be seen as an early analogy to the Christian Church, where the opening to the secular world is on the west side, but prayer for dialogue with higher powers take place against the eastern wall, which presents no opening, like the apse of a church. Man's path to spiritual perfection was associated with nature, the Universe, and symbols of geometric signs.

3. The ancient Greeks built sacral buildings of stone in places of worship, but in the Christian era, types of buildings for cult rituals began to develop. The construction of shrines followed ancient principles: buildings included domes indicating a connection to the Universe and elements related to the cosmos.

4. In Jerusalem, the Cross Way of religious processions was particularly important, but in the urban environment of Rome and Constantinople, the Way became the main element of the layout composition. Buildings for religious rituals were developed in the urban environment, and it was subordinate and connected to the road, which had a functional and symbolic meaning.

\section{References}

Adamchik, M. V. (2005). Arhitektura. Kratkij spravochnik. Moskva, Minsk: AST, Harvest. Apals, J. (1986). Arheoloǵiskie pieminekl̦i Gaujas Nacionālajā parkā. Rīga: Zinātne.

Apals, J. (1996). Senie mājokḷi Latvijā. No vissenākajiem laikiem līdz 13. gs. Rīga: RAKA. Celms, V. (2016). Baltu dievestības pamati = Baltu religijos pagrindai. Rīga: Lauku Avīze. Colabella, E. (2017). Generative art language. In XX Generative Art Conference Proceedings. Milan: Domus Argenia Publisher, 125-139. 
Proceedings of the International Scientific Conference. Volume IV, May $28^{\text {th }}-29^{\text {th }}$, 2021. 626-652

Hubner, F., R. von (1899). Map of Byzantine Constantinople. London: Walker\&Bontall sc. Jordan, H. (1886). Map of ancient Rome City. In Professor G. Droysens Allgemeiner historischer Handatlas in sechsundneunzig Karten, mit erläuterndem Text. Bielefeld, Leipzig: Velhagen \& Klasing.

Lanciani, R. (1893-1901). Roma. Plan of Papal Basilica of Saint Peter instead of the Circus of Nero. In Rodolfo Amedeo Lanciani, Luigi Salomone, Ulrico Hoepli, Accademia nazionale dei Lincei. (1893-1901). Forma Urbis Romae. Mediolani: Apud Ulricum Hoepli.

Le Roy, J., D. (1770). Les ruines des plus beaux monuments de la Grece, considérées du côté de l'histoire et du côté de l'architecture. Vol. I. Paris: Louis-François Delatour.

Ozola, S. (2017). Ethnographic symbols in Latvian regional architecture. In XX Generative Art Conference Proceedings, Milan: Domus Argenia Publisher, 353-394.

Reeves, N. (2017). Origin point: harmonic echoes of mineral cosmology (Mende Cathedral). In XX Generative Art Conference Proceedings, Milan: Domus Argenia Publisher, 288-319.

Soddu, C. (2016). The discovering persistent deep memory in generative design. In XIX Generative Art Conference Proceedings, Milan: Domus Argenia Publisher, 15-35. 